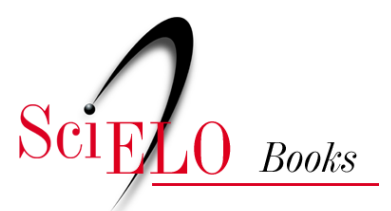

\title{
Caminho das tropas
}

\author{
José Carlos Radin \\ Gentil Corazza
}

\section{SciELO Books / SciELO Livros / SciELO Libros}

RADIN, J.C., and CORAZZA, G. Caminho das tropas. In: Dicionário histórico-social do Oeste catarinense [online]. Chapecó: Editora UFFS, 2018, pp. 32-34. ISBN: 978-85-64905-65-8. https://doi.org/10.7476/9788564905658.0007.

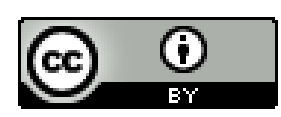

All the contents of this work, except where otherwise noted, is licensed under a Creative Commons Attribution 4.0 International license.

Todo o conteúdo deste trabalho, exceto quando houver ressalva, é publicado sob a licença Creative Commons Atribição 4.0.

Todo el contenido de esta obra, excepto donde se indique lo contrario, está bajo licencia de la licencia $\underline{\text { Creative Commons }}$ Reconocimento 4.0. 


\section{Caminho das tropas}

O chamado "Caminho das tropas" atravessava o território do Oeste catarinense, tendo seu auge entre meados do século XVIII e meados do século XIX. Ele foi aberto com o objetivo de tropear o gado xucro dos campos gaúchos até as feiras de Sorocaba para alimentar os trabalhadores do café de São Paulo e da mineração em Minas Gerais. Na realidade, houve dois caminhos das tropas: o primeiro deles teria sido aberto por volta de 1728, ligando os campos de Viamão, no Rio Grande do Sul, a Sorocaba, em São Paulo, através dos campos de Lages, território que passou a desempenhar um papel central nesta fase pecuária da economia catarinense. Sorocaba era o maior centro comercializador de animais do país, chegando a reunir, em algumas ocasiões, mais de 200 mil cabeças. Por muitos anos, os animais eram tropeadas do Sul para o Sudeste por este caminho. A ocupação do território em torno desse primeiro caminho durou quase um século, quando, então, se começou a desenhar um segundo caminho das tropas, com as mesmas funções e impactos do primeiro. Por volta de 1810, novas fazendas foram criadas nos campos de Guarapuava, e, em torno de 1838, inúmeras outras se formaram nos campos de Palmas. Foi sobretudo a partir de Palmas e Guarapuava que fazendeiros, vindos do Norte, avançaram mais para o atual Oeste de Santa Catarina, atingindo as terras onde atualmente se situa Campo Erê.

O motivo principal desse deslocamento da ocupação para o Oeste foi que Lages, em 1820, até então ainda fazendo parte da Província de São Paulo, foi incorporada à Província de Santa Catarina e passou a cobrar impostos pela passagem do gado. Em função disso e do avanço das fazendas para o Oeste, foi aberto um novo caminho, entre o Sul e o Sudeste, que estivesse livre da tributação imposta pela comarca de Lages. Esse segundo caminho cortou uma região onde eram mais abundantes os ervais nativos, cuja extração começou a tornar-se atrativa, especialmente para a população sertaneja, que passou a ter nela sua principal forma de interação comercial. O trânsito mais intenso de tropas pelas terras do Oeste, entre as quais estavam as que 
posteriormente foram motivo de disputa pelos estados do Paraná e de Santa Catarina, propiciou a formação de novos pousos, a partir dos quais surgiram novas vilas e a penetração mais intensa de brasileiros em busca da exploração da erva-mate.

Ao longo desses caminhos foi se dando a ocupação do território através da implantação de fazendas para criar gado e do estabelecimento de novos povoados que vieram somar-se aos povoados indígenas já existentes. A ocupação das terras do Oeste com fazendas de criação de gado, além de contribuir para a produção de alimentos, sobretudo para a região dos cafezais paulistas, fazia parte da estratégia de ocupação deste território de fronteira traçada pelos colonizadores portugueses e reforçada por Dom João VI, a partir de 1808. As fazendas eram, de fato, a forma mais rápida, barata e segura de ocupação daquele território. Para fixar esses fazendeiros na região, o governo fazia concessões de terras aos seus ocupantes. Essa fase de formação das fazendas e abertura dos "caminhos das tropas" é considerada como a "fase pecuária" da formação econômica do Oeste de Santa Catarina (BAVARESCO, 2003).

No entanto, além de promover a ocupação dos campos e uma maior e mais profunda penetração populacional no Oeste, a criação de gado teve pouca importância para a formação das bases econômicas da região, pois os fazendeiros não se preocupavam em colonizar as áreas que ocupavam, em função das dificuldades que o cultivo da terra implicava naquela época. Por isso, a agricultura pouco se desenvolveu nesta fase pecuária e as fazendas formavam uma espécie de arquipélagos numa paisagem ainda pouco povoada pelas populações indígenas. Em consequência, o ciclo da pecuária pouco contribuiu para a acumulação original de capital e o posterior desenvolvimento econômico da região. O capital circulante era escasso, em geral associado à comercialização de gado e de alimentos. Diferentemente do que ocorreu no Rio Grande do Sul, no Oeste catarinense não vingou nem a indústria das charqueadas, nem a pequena indústria do couro. A marca desse ciclo da pecuária foi a conquista do território através do latifúndio e da expulsão da população indígena que ali vivia. No entanto, à sua maneira, o ciclo da pecuária teve seu papel para o início 
da formação econômica da região e seu posterior desenvolvimento, pois foi a partir dessa ocupação do território com grandes fazendas que, depois, foram se abrindo meios de transporte e melhorando os meios de comunicação.

Por volta de 1870, com o declínio do ciclo das tropas e das fazendas de criar, processa-se a dispersão da família fazendeira e a fragmentação das grandes áreas de criação de gado. (RENK, 1997). Depois da ocupação dos campos, vinda do Norte, se deu a ocupação das matas, pela população cabocla, e por fim a ocupação pela colonização, a qual inaugura um novo capítulo na história econômica e social desta região.

O declínio do tropeirismo de gado também se explica pelo avanço das ferrovias, que teve grande expansão no final do Império. Mesmo assim, a prática do tropeirismo persistiu até recentemente, quando tropas menores eram deslocadas para frigoríficos. Saliente-se, ainda, que no período da colonização essa prática também foi usada para conduzir suínos, seja para frigoríficos ou para as estações da ferrovia, de onde seguiam para a comercialização.

\section{REFERÊNCIAS}

ALMEIDA, Leo. Tropeiros.(Música).Disponível em: $<$ https://www. youtube.com/watch?v=jHPla4EG3sU>. Acesso em: 20 mar. 2017. BAVARESCO, Paulo Ricardo. Os Ciclos Econômicos do Extremo Oeste Catarinense: modernização, progresso e empobrecimento. (Dissertação de Mestrado). Blumenau: 2003.

PIMENTEL, Airton e FAGUNDES, Antônio Augusto. (música) Tropeiro de Mulas. Interpretação de Daniel Torres. DVD - Tropeiros - Globo Rural. RENK, Arlene. A luta da erva: um ofício étnico no oeste catarinense. Chapecó: Grifos, 1997. 